\title{
Short Communication: Effect of Exopolysaccharide Isolated from "Viili" on the Adhesion of Probiotics and Pathogens to Intestinal Mucus
}

\author{
P. Ruas-Madiedo, ${ }^{\star} \dagger^{1}$ M. Gueimonde, ${ }^{\star}$ C. G. de los Reyes-Gavilán, $\dagger$ and S. Salminen ${ }^{\star}$ \\ ${ }^{*}$ Functional Foods Forum, University of Turku. Itäinen Pitkäkatu 4A, FIN 20014, Turku, Finland \\ †Instituto de Productos Lácteos de Asturias (CSIC), Carretera de Infiesto s/n, 33300 Villaviciosa, Asturias, Spain
}

\begin{abstract}
The strong ropy character of the Scandinavian fermented milk viili is conferred by the exopolysaccharides (EPS) produced by lactococcal strains. These biopolymers can be responsible for some health benefits. We have assessed the influence of the EPS fraction isolated from commercial viili on the adhesion of some probiotics and pathogens to human intestinal mucus. Concentrations of viili EPS greater than $0.1 \mathrm{mg} / \mathrm{mL}$ promoted a decrease in adherence of Bifidobacterium lactis Bb12 and Lactobacillus rhamnosus GG and this effect was dose-dependent. However, no modifications were detected on the adhesion levels of the pathogenic strains tested at a concentration of $1 \mathrm{mg} / \mathrm{mL}$ of EPS. Results obtained in the present work should be considered in the design of new probiotic products.
\end{abstract}

Key words: exopolysaccharide, adhesion, probiotic, intestinal mucus

Exopolysaccharide (EPS)-producing lactic acid bacteria are commonly used as starter cultures in the manufacture of yogurt, kefir, and some Scandinavian fermented milks such as "långfil" in Sweden, or "viili" in Finland (Duboc and Mollet, 2001). Viili is made with a traditional mesophilic mixed-strain starter mainly composed of Lactococcus lactis ssp. cremoris EPS-producing strains that confer its strong ropy character (Saxelin et al., 1986). The EPS from viili is a pentasaccharide composed of galactose, glucose, and rhamnose in similar ratios (2:2:1), and has an anionic nature due to the presence of a phosphate group. The physical properties of this EPS in aqueous solutions (Tuinier et al., 1999; Higashimura et al., 2000) as well as its viscosity-intensifying ability in fermented skimmed milk (Ruas-Madiedo et al., 2002) have been determined. In addition, it has been suggested that this biopolymer could reduce the blood cholesterol level of rats (Nakajima et al., 1992), and that it has anticarcinogenic ability (Kitazawa et

Received January 18, 2006.

Accepted February 20, 2006

${ }^{1}$ Corresponding author: ruas-madiedo@ipla.csic.es al., 1991) mediated by the stimulation of the mitogenic activity of B lymphocytes (Kitazawa et al., 1992).

Probiotics have been defined as "viable microorganisms that exhibit a beneficial effect on the health of the host when they are ingested" (Salminen et al., 1998). Strains of the genera Lactobacillus and Bifidobacterium are the most common probiotics used for human consumption; they can be present together with other lactic acid bacterial starters in commercial dairy products (Playne et al., 2003; Talwalkar and Kailasapathy, 2004). One of the main criteria for the selection of probiotics is the ability to adhere to the intestinal mucosa allowing a transitory colonization of the intestinal tract, which could modify the adhesion of other microorganisms (Dunne et al., 2001). Ouwehand and coworkers (2000) have shown that the presence of Lactobacillus rhamnosus GG resulted in a 2-fold increase in the adherence of Bifidobacterium lactis Bb12 to a human mucus model, suggesting a synergistic effect. However, no studies are currently available about the influence of EPS included in commercial products on the adhesion of probiotics. In the present work, we evaluated the adhesion properties to human intestinal mucus of 2 common probiotics found in the market, Bifidobacterium animalis ssp. lactis Bb12 and $L b$. rhamnosus GG, as affected by the presence of the EPS isolated from commercial fermented milk, viili. The ability of this EPS to interfere with the adhesion of several enteric pathogens was also investigated.

Three different batches of the commercial fermented milk viili containing $1 \%$ fat were purchased from the supermarket. For EPS isolation, TCA was added to obtain a final concentration of $12 \%(\mathrm{wt} / \mathrm{wt})$, and the mixture was vigorously stirred for $1 \mathrm{~h}$ at room temperature. Microorganisms and precipitated milk proteins were removed by centrifugation. Each EPS fraction was precipitated with 2 volumes of absolute ethanol $\left(4^{\circ} \mathrm{C}\right.$ for 48 h), resuspended in ultrapure water, dialyzed $\left(3 \mathrm{~d}, 4^{\circ} \mathrm{C}\right.$, molecular weight cut off: 12 to $14 \mathrm{kDa}$ ), and finally lyophilized. For the adhesion experiments, the viili EPS fractions were resuspended at different concentrations $(0.1$, 0.5 , and $1.0 \mathrm{mg} / \mathrm{mL}$ ) in HEPES-Hanks' buffer (HH), $\mathrm{pH}$ 7.4 (10 $\mathrm{m} M$ HEPES). The polymer yield of the EPSviili was determined by gel permeation chromatography. Exopolysaccharide fractions $(100 \mu \mathrm{L})$ were analyzed in a 
TSK-GEL G5000PW $\mathrm{XL}_{\mathrm{XL}}$ (Supelco/Sigma-Aldrich Química S.A., Madrid, Spain) column protected with a TSK-GEL PW guard column (Supelco). The EPS was isocratically separated at a flow rate of $0.6 \mathrm{~mL} / \mathrm{min}$ at $40^{\circ} \mathrm{C}$ using 0.1 $M \mathrm{NaNO}_{3}$ as the mobile phase. A PDA 996 detector (Waters, Milford, MA) was used to check the absence of protein in the elution peak corresponding to the EPS and a 410 Refractometer (Waters) was used for the quantification of the polymer. The EPS concentration (mg/ $\mathrm{mL}$ ) and molar mass (Da) were obtained using the linear regression equations $\left(R^{2} \geq 0.994\right.$ and $R^{2} \geq 0.999$, respectively) calculated from different molar mass standards of dextran. Finally, the protein content of the viili EPS fraction was measured using the bicinchoninic acid (BCA) protein assay kit (Pierce, Rockford, IL), following the manufacturer's instructions.

A human intestinal mucus model (Ouwehand et al., 2002) was used to assess the effect of the EPS in the adhesion of the probiotics $L b$. rhamnosus GG and $B$. animalis ssp. lactis $\mathrm{Bb} 12$ and the pathogens Listeria monocytogenes ATCC 15313, Clostridium difficile ATCC 9689, Enterobacter sakazakii ATCC 29544, Salmonella enterica biovar. Typhimurium ATCC 29631, and Escherichia coli NCTC 8603. Probiotics were grown overnight in MRS-cysteine (at $37^{\circ} \mathrm{C}$ in anaerobic conditions) and pathogens were grown in Gifu anaerobic medium (Nissui Pharmaceuticals, Tokyo, Japan) broth at $37^{\circ} \mathrm{C}$ in the presence of $10 \mu \mathrm{Ci} / \mathrm{mL}$ of tritiated thymidine $\left(5-{ }^{3} \mathrm{H}\right.$-thymidine, specific activity: $120 \mathrm{Ci} / \mathrm{mmol}$; Amersham Bioscience, Buckinghamshire, UK). Standardized (optical density at $600 \mathrm{~nm}: 0.25 \pm 0.01$ ) cell suspensions were prepared in HH buffer without and with different concentrations of the EPS from viili, and bacterial adhesion was determined according to Kirjavainen and coworkers (1998). In short, $100 \mu \mathrm{L}$ of intestinal mucus was immobilized on polystyrene microtiter plate wells by overnight incubation at $4^{\circ} \mathrm{C}$. After washing twice with $\mathrm{HH}$ buffer, wells were filled with $100 \mu \mathrm{L}$ of the standardized bacterial suspensions, and incubated for $1 \mathrm{~h}$ at $37^{\circ} \mathrm{C}$. Afterwards, the unattached bacteria were removed by washing twice with $\mathrm{HH}$ buffer, and the adhering cells were released and lysed with $200 \mu \mathrm{L}$ of lysis solution [1\% (wt/ vol) SDS in $0.1 \mathrm{M} \mathrm{NaOH}]$ at $60^{\circ} \mathrm{C}$ for $1 \mathrm{~h}$. The content of wells was transferred to microfuge tubes containing scintillation liquid (OptiPhase HiSafe 3, Wallac Oy, Turku, Finland), and the radioactivity of lysed bacteria was determined with a liquid scintillation counter. Adhesion results were expressed as the percentage of radioactivity recovered after adhesion relative to the radioactivity of the bacterial suspension initially added to the immobilized mucus. Experiments were carried out at least in triplicate and 1-way ANOVA was performed to determine the effect of EPS concentration on the adhesion of strains tested.
Table 1. Lactococcal counts, $\mathrm{pH}$ values, and exopolysaccharides (EPS) yield from the commercial fermented milk, viili, used in this study

\begin{tabular}{lr}
\hline & Mean \pm SD \\
\hline Fermented milk viili & \\
Lactococcal counts $($ log cfu/mL) & $8.07 \pm 0.25$ \\
pH & $4.35 \pm 0.03$ \\
EPS yield $(\mathrm{mg} / \mathrm{kg}$ of viili) & $71.45 \pm 9.91$ \\
EPS fraction ${ }^{1}$ & \\
Protein content $(\% \mathrm{wt} / \mathrm{wt})$ & $3.67 \pm 1.09$ \\
EPS content $(\% \mathrm{wt} / \mathrm{wt})$ & $79.80 \pm 15.31$ \\
Molar mass $\left(\times 10^{6} \mathrm{Da}\right)$ & $10.41 \pm 2.12$ \\
\hline
\end{tabular}

${ }^{1}$ Protein and EPS content of the viili EPS fraction were obtained after the purification procedure; molar mass represents the average molar mass of the purified EPS.

The lactococcal counts, $\mathrm{pH}$, and EPS yield of the 3 batches of viili analyzed are shown in Table 1 . The $\mathrm{pH}$ values of viili were around 4.35 and the bacterial counts on M17 agar ranged from 7.82 to $8.32 \log \mathrm{cfu} / \mathrm{mL}$. The EPS yield measured by gel permeation chromatography was around $71 \mathrm{mg} / \mathrm{kg}$ of viili. No previous data were available in literature concerning the EPS yield from commercial viili. However, our results were similar to that obtained in skimmed milks fermented with several viili lactococcal strains, in which yields of single independent cultures varied from 40 to $80 \mathrm{mg} / \mathrm{L}$ as measured by gel permeation chromatography (Ruas-Madiedo et al., 2002). Higher EPS yields (from 164 to $263 \mathrm{mg} / \mathrm{L}$ ) were obtained by a colorimetric method with other lactococcal strains growing in skimmed milk (Yang et al., 1999). In addition to the type of strains used for fermentation, differences in milk composition, incubation temperature, EPS isolation procedure, and EPS quantification methods could account for the variability in the EPS yield reported by different authors (Ruas-Madiedo and de los Reyes-Gavilán, 2005). Polysaccharide was the major component of the EPS fraction, comprising around $80 \%$ (wt/wt), and the protein content was lower than 4\% (wt/ wt; Table 1). The average molar mass of the EPS viili was around $10 \times 10^{6} \mathrm{Da}$ (Table 1), distributed in a single nonuniform peak. The reported size of the EPS produced by several viili lactococcal strains is lower, ranging between $2.5 \times 10^{4}$ and $1.4 \times 10^{6} \mathrm{Da}$ (Ruas-Madiedo and de los Reyes-Gavilán, 2005). The considerable width of our peak of EPS from viili pointed to the presence of polymers of different sizes. Probably, the aggregation between some EPS molecules would account for the high molar mass values detected in our case.

Figure 1 shows the adhesion levels to human intestinal mucus of the commercial probiotic strains $L b$. rhamnosus GG and $B$. animalis ssp. lactis $\mathrm{Bb} 12$. In the absence of the polymer, the probiotic strains showed good adherence to human intestinal mucus with levels comparable to those previously reported (Ouwehand et al., 
Lactobacillus rhamnosus GG

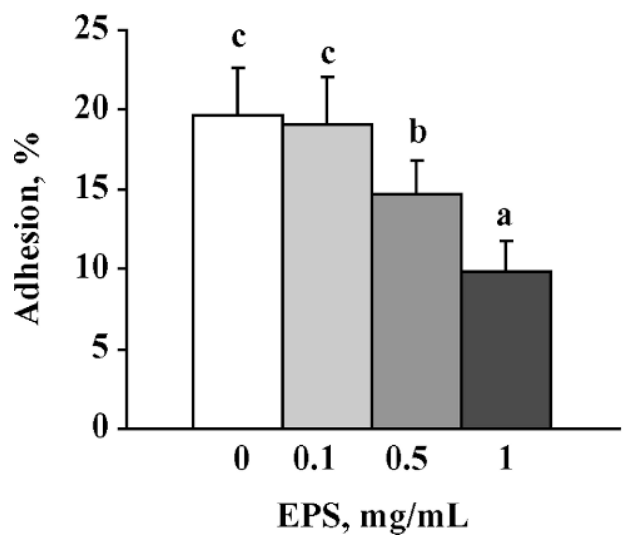

Bifidobacterium animalis ssp. lactis Bb 12

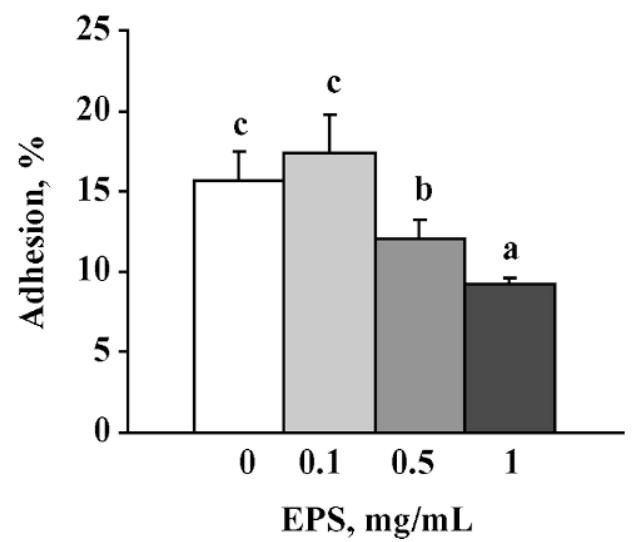

Figure 1. Adhesion to human intestinal mucus of the probiotics strains Lactobacillus rhamnosus GG and Bifodobacterium animalis ssp. lactis $\mathrm{Bb} 12$ in the presence of increasing concentrations $(0,0.1,0.5$, and $1 \mathrm{mg} / \mathrm{mL})$ of the exopolysaccharide (EPS) fraction isolated from the commercial fermented milk, viili. Bars with different superscript letters within each plot are significantly different $(P<0.05)$.

2000; Gueimonde et al., 2005). However, the adherence of both strains significantly decreased $(P<0.001)$ when the EPS was present at concentrations higher than 0.1 $\mathrm{mg} / \mathrm{mL}$, with the effect being dose-dependent. This concentration is close to that found in the commercial viili $(0.071 \mathrm{mg} / \mathrm{mL})$ analyzed in the present work. The minimum adhesion was obtained at EPS concentrations of 1 $\mathrm{mg} / \mathrm{mL}$, at which a decrease of 2 -fold and 1.7 -fold with respect to the control (without EPS) was detected for $L b$. rhamnosus GG and B. lactis Bb12, respectively. These results indicated that the EPS villi fraction could competitively inhibit adhesion to human intestinal mucus of the commercial probiotics tested.

The effect of EPS from viili on the adhesion of 5 pathogens to mucus is shown in Figure 2. In general, the adhesion level of the pathogens analyzed was lower than that of the probiotic bacteria. The En. sakazakii and $E$. coli strains displayed the highest adhesion levels (between 6 and 8\%), whereas $S$. enterica biovar. Typhimurium and $C$. difficile showed values around $3 \%$. The low-

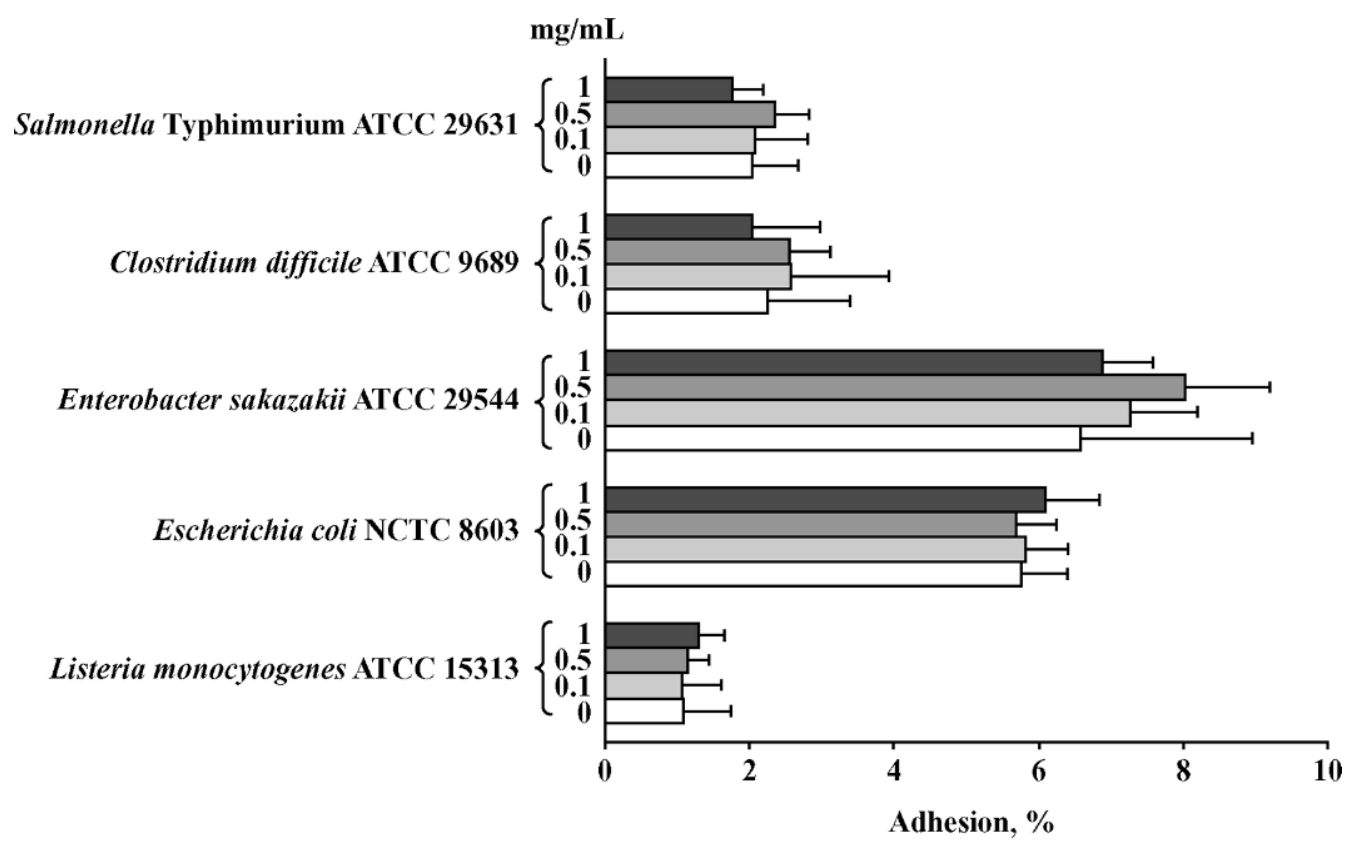

Figure 2. Adhesion to human intestinal mucus of several enteric pathogens in the presence of increasing concentrations $(0,0.1,0.5$, and $1 \mathrm{mg} / \mathrm{mL}$ ) of the exopolysaccharide (EPS) fraction isolated from the commercial fermented milk, viili. 
est level of adhesion was found with $L$. monocytogenes with values around $1 \%$, which indicates a very poor adherence capability. The results obtained were slightly lower than those recently reported for the same microorganisms (Collado et al., 2005), and could be due to the different origin of human mucus used in each case. Contrary to the results obtained for probiotic strains, no significant differences $(P>0.05)$ attributable to the presence of the EPS fraction were detected on the adhesion of the 5 pathogenic strains tested.

In this study, we have shown that the EPS fraction isolated from the commercial fermented milk, viili, caused a decrease in the adhesion of the commercial probiotic strains $L b$. rhamnosus GG and B. animalis ssp. lactis Bb12 without modifying adherence of some pathogens to human intestinal mucus. This could indicate that factors involved in the adhesion of probiotics and pathogens to mucus could be different. It also seems that the effect of EPS on adhesion is dependent on the strain tested. Our preliminary results suggest that the EPS from viili could compete in vitro for similar adhesion targets on the mucus as well as probiotic strains or that it could attach to the cellular surface of probiotics. Further studies on the effect of EPS from lactic bacteria on bacterial adhesion are needed to establish a mechanism of action. On the other hand, the effect of EPS against the adhesion of probiotic bacteria was detected in doses of EPS $(0.1 \mathrm{mg} / \mathrm{mL})$ close to that found in the commercial fermented milk. Thereby, the possible effect of EPS produced by the Lc. lactis ssp. cremoris strains included in fermented milks on the adhesion to intestinal mucus of probiotics should be considered in the design of new probiotic products.

\section{ACKNOWLEDGMENTS}

This work was financed by European Union FEDER funds through the Spanish "Plan Nacional de I+D" (Project AGL2004-06088-CO2-01) and the Akademy of Finland. P. Ruas-Madiedo was supported by an I3P postdoctoral research contract granted by CSIC and FEDER funds. We are grateful for the collaboration of J. Meriluoto and L. Spoof (Åbo Akademi University, Turku, Finland) for the availability of some equipment and their technical assistance.

\section{REFERENCES}

Collado, M. C., M. Gueimonde, M. Hernández, Y. Sanz, and S. Salminen. 2005. Adhesion of selected Bifidobacterium strains to human intestinal mucus and inhibition of adhesion of entero-pathogens. J. Food Prot. 68:2672-2678.

Duboc, P., and M. Mollet. 2001. Applications of exopolysaccharides in the dairy industry. Int. Dairy J. 11:759-768.

Dunne, C., L. O’Mahony, L. Murphy, G. Thornton, D. Morrissey, S. O'Halloran, M. Feeny, S. Flynn, G. Fitzgerald, C. Daly, B. Kiely, G. C. O'Sullivan, F. Shanahan, and J. Collins. 2001. In vitro selection criteria for probiotic bacteria for human origin: Correlation with in vivo findings. Am. J. Clin. Nutr. 73:386S-392S.

Gueimonde, M., L. Noriega, A. Margolles, C. G. de los Reyes-Gavilán, and S. Salminen. 2005. Ability of Bifidobacterium strains with acquired resistance to bile to adhere to human intestinal mucus. Int. J. Food Microbiol. 101:342-346.

Higashimura, M., B. W. Mulder-Bosman, R. Reich, T. Iwasaki, and G. W. Robjin. 2000. Solution properties of viilian, the exopolysaccharide from Lactococcus lactis subsp. cremoris SBT 0495. Biopolymers 54:143-158.

Kirjavainen, P. V., A. C. Ouwehand, E. Isolauri, and S. J. Salminen. 1998. The ability of probiotic bacteria to bind to human intestinal mucus. FEMS Microbiol. Lett. 167:185-189.

Kitazawa, H., T. Toba, T. Itoh, N. Kumano, S. Adachi, and T. Yamaguchi. 1991. Antitumoral activity of slime-forming, encapsulated Lactococcus lactis spp. cremoris isolated from Scandinavian ropy sour milk "viili". Anim. Sci. Technol. (Jpn.) 62:277-283.

Kitazawa, H., T. Yamaguchi, and T. Itoh. 1992. B-cell mitogenic activity of slime products produced from slime-forming, encapsulated Lactococcus lactis ssp. cremoris. J. Dairy Sci. 75:2946-2951.

Nakajima, H., Y. Suzuki, H. Kaizu, and T. Hirota. 1992. Cholesterol lowering activity of ropy fermented milk. J. Food Sci. 57:13271329 .

Ouwehand, A. C., E. Isolauri, P. V. Kirjavainen, S. Tölkkö, and S. J. Salminen. 2000. The mucus binding of Bifidobacterium lactis Bb12 is enhanced in the presence of Lactobacillus GG and Lact. delbrueckii subsp. bulgaricus. Lett. Appl. Microbiol. 30:10-13.

Ouwehand, A. C., S. Salminen, S. Tölkkö, P. Roberts, J. Ovaska, and E. Salminen. 2002. Resected human colonic tissue: New model for characterizing adhesion of lactic acid bacteria. Clin. Diagn. Lab. Immunol. 9:184-186.

Playne, M. J., L. E. Bennett, and G. W. Smithers. 2003. Functional dairy foods and ingredients. Aust. J. Dairy Technol. 58:242-264.

Ruas-Madiedo, P., and C. G. de los Reyes-Gavilán. 2005. Invited review: Methods for the screening, isolation and characterization of exopolysaccharides produced by lactic acid bacteria. J. Dairy Sci. 88:843-856.

Ruas-Madiedo, P., R. Tuinier, M. Kanning, and P. Zoon. 2002. Role of exopolysaccharides produced by Lactococcus lactis subsp. cremoris on the viscosity of fermented milks. Int. Dairy J. 12:689-695.

Salminen, S., A. von Wright, L. Morelli, P. Marteau, D. Brassart, W. M. de Vos, R. Fonden, M. Saxelin, K. Collins, G. Mogensen, S. E. Birkeland, and T. Mattila-Sandholm. 1998. Demonstration of safety of probiotics - A review. Int. J. Food Microbiol. 44:93-106.

Saxelin, M. L., E. L. Nurmiaho-Lassila, V. T. Merilainen, and R. I. Forsén. 1986. Ultrastructure and host specificity of bacteriophages of Streptococcus cremoris, Streptococcus lactis subsp. diacetylactis, and Leuconostoc cremoris from Finnish fermented milk "viili". Appl. Environ. Microbiol. 52:771-777.

Talwalkar, A., and K. Kailasapathy. 2004. Comparison of selective and differential media for the accurate enumeration of strains of Lactobacillus acidophilus, Bifidobacterium spp. and Lactobacillus casei complex from commercial yoghurts. Int. Dairy J. 14:143-149.

Tuinier, R., P. Zoon, C. Olieman, M. A. Cohen-Stuart, G. J. Fleer, and C. de Kruif. 1999. Isolation and physical characterization of an exocellular polysaccharide. Biopolymers 49:1-9.

Yang, Z., E. Huttunen, M. Staaf, G. Widmalm, and H. Tenhu. 1999. Separation, purification and characterisation of extracellular polysaccharides produced by slime-forming Lactococcus lactis ssp. cremoris strains. Int. Dairy J. 9:631-638. 